\title{
Is Optimum Currency Area Feasible In East Asia? A Regional Study On Mainland China And Hong Kong
}

Hong Zhuang, Indiana University South Bend, USA

\begin{abstract}
This paper evaluates the possibility of forming a common currency area in Mainland China and Hong Kong using five economic indices that are used as criterion for the optimality of a currency area in the literature and finds mixed results. The higher product diversification in Mainland China, low correlations in real output growth, money growth, nominal interest rate and real interest rate, dissimilarity of industry structures and inflation rates do not support the formation of a currency union between the two regions. However, the analysis of degrees of openness is in favor of Hong Kong forming a monetary union with Mainland China.
\end{abstract}

Keywords: Optimum Currency Area; Monetary Union

\section{INTRODUCTION}

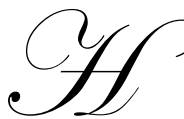

ong Kong was returned to Chinese sovereign on July 1, 1997 after being British's colony for 100 years and becomes one of the special administrative regions (SAR) in China. However, Hong Kong still has the independent currency and determines its own monetary policy. Considering the tremendous trade volume and close economic connection between Mainland China and Hong Kong, the exchange between Chinese Yen and Hong Kong Dollar increases the transaction cost and reduces the economic efficiency. Furthermore, a closer look at the people, geography, culture, history and politics in Mainland China and Hong Kong would make it interesting to evaluate the possibility of establishing a monetary union in the two regions.

Therefore, this paper attempts to use the theory of optimum currency areas (OCA) to assess the possibility of Mainland China and Hong Kong to form a monetary union. Several indices that are used as criterion for the optimality of a currency area are applied to evaluate the hypothesis. In reality, economic conditions may not be the only decisive reasons for the formation of a monetary union. Other elements, such as historical, cultural and political, may also play important parts in influencing the decision. However, the focus of this paper is on the economic possibility of forming a monetary union.

The rest of the paper is organized as follows. Section II discusses the theories of optimum currency areas and review relevant literature. Section III is the empirical analysis, which examines whether Hong Kong should constitute a monetary union with Mainland China. Section IV concludes the paper.

\section{LITERATURE REVIEW}

An optimum currency area is a region for which it is optimal to have a single monetary policy and a single currency (Frankel, 1999). The theoretical foundation is raised by Mundell's seminal paper in 1961. Other researcher, for example, McKinnon (1963) and Kenen (1969), explore the issues of optimum currency areas following Mundell's work (Mkenda, 2001). With the development and deepening in research of macroeconomic areas over time, the theory of optimum currency areas has been extended and modified. The fundamental literature on optimum currency areas focuses on two important issues. One issue is the costs and benefits of adopting a common currency. The other one is the characteristics that are desirable for countries to consider money unions (Tavlas 1993). 
It is widely recognized that exchange rate certainty is the motive to pursue the optimum currency area. Furthermore, the benefits of a common currency also include the reduced risk from uncertainty in the movement of the exchange rates (DE Grauwe, 1997), the elimination of the transaction costs associated with currency conversion as well as the information cost of processing and storing information about multiple currencies, and the potential to reinforce the discipline and credibility (Dupasquier and Jacob, 1997).

The costs of a common currency are the loss of independence over exchange rate policies and the inability to use monetary policies for domestic objectives. When the exchange rate is no longer an instrument, the country loses a mechanism for protecting itself from economic shocks. It would be less costly if the economic shocks affect all the members of the currency union symmetrically, because the common policy response would be appropriate (Mkenda, 2001). However, if the shocks are asymmetric, the lack of ability to use the exchange rate policy to make corresponding adjustment would cause greater variability in output and employment. Furthermore, the costs of integrated monetary and exchange rate policies are lessened if price and wages are more flexible and labor is mobile enough (De Grauwe, 1997; Dupasquier and Jacob, 1997).

The following characteristics are proposed in the literature as keys in deciding whether countries may join a currency union and adopt a common currency.

\section{Factor Mobility}

High mobility of factors provides a substitute for exchange rate flexibility in adjustment when a disturbance occurs (Mundell, 1961). Hence, potential members who show a high degree of factor mobility in between are viewed as better candidates for a monetary union.

\section{Openness and Size of an Economy}

In an optimum currency area, the member countries maintain a fixed exchange rate between each other, indicating that an individual country within the area can not unilaterally depreciate or appreciate its currency. It is favorable for highly open economies to choose fixed exchange rate regimes, since nominal exchange rate is less effective as a policy instrument for adjustment. Moreover, in open economies, frequent exchange rate adjustments diminish price stability since the overall price index would vary more than that in relatively closed economies (McKinnon, 1963). Consequently, a small open country is more inclined to join a monetary union.

\section{Degrees of Commodity Diversification}

An economy which is highly diversified in products would export a wider variety of products. If the demand for some of its products decreases, the shock would not result in a large fall in employment. However, for a less diversified economy, similar shock would have a higher overall effect on the economy. Hence, an economy with high degrees of diversification is more qualified for the common currency area and does not need to frequently change its nominal exchange rate in case of external economic shocks.

\section{Flexibility of Prices and Wages}

If prices and wages are flexible between and among the regions, the need of using the exchange rate for adjustment is diminished, because unemployment in one region and inflation in another are not likely to occur during transition toward adjustment (Mkenda, 2001).

\section{Similar Industrial Structure}

Countries that possess similar industrial structures are more likely subject to symmetric terms-of-trade shocks, negating the need to implement a unilateral adjustment in the exchange rate between the countries. Therefore, countries with similar industrial structures are better candidates for the common currency area (Mundell, 1961; Dellas and Tavlas, 2001). 


\section{High Co-variation in Economies}

Countries that show high correlations in economic activities are still suitable for the common currency area, even if they may have different industrial structure. Those countries are prone to experience similar economic shocks, which reduces the importance of independent exchange rate policies to make appropriate adjustment (Bayoumi and Ostry, 1997; Jonung and Sjoholm, 1998).

\section{Similarity in inflation rates}

Different inflation rates between countries imply difference in ways they conduct economic policies and differences in economic structures. Therefore, it is better for countries with similar inflation rates to join the common currency area (Jonung and Sjoholm, 1998; Mkenda, 2001).

\section{Political Factors}

Political factors play an important part in the formation of a monetary union. To be more specific, the strong political will and public support are two necessary factors in process towards a monetary union, because belonging to a monetary union must include agreement on cooperation of policies with other members. The general public may not favor that, but the government leader must make commitment and decision to convince the public so that the country can benefit from the monetary union. Without political will and public support, the commitment to the monetary union cannot be realized, which can lead to the demise of the union (Jonung and Sjoholm, 1998; Mkenda, 2001).

\section{EMPIRICAL ANALYSIS}

The following economic indices are computed to evaluate the likelihood for Mainland China and Hong Kong to form a optimum currency area.

\section{Degrees of Product Diversification}

This refers to the extent to which the industrial structure is diversified in goods production. A more diversified industrial structure would enable countries in the currency union to absorb shocks to a particular sector. I construct Herfindahl Indices for Mainland China and Hong Kong respectively. The Herfindahl Index is given by the following equation:

\section{Product Diversification $_{i}=100 * \sum \mathrm{S}_{\mathrm{j}}^{2}$}

Where $S_{j}$ is the fraction occupied by sector $\mathrm{j}$ in manufacturing value added in country $i$. A higher value indicates a smaller degree of product diversification. The value of the index ranges from 0 to 100 . The data on manufacturing industrial value added are from the International Yearbook of Industrial Statistics published by the United Nations Industrial Development Organization (UNIDO) over the period of 1996-2003 and classified at the three-digit level of International Standard Industrial Classification (ISIC). Table 1 shows the Herfindahl indices in Mainland China and Hong Kong from 1996 to 2003. Although both regions present decreased Herfindahl indices over time, Mainland China shows higher product diversification than Hong Kong overall. The average Herfindahl Indices of Mainland China from 1996 to 2003 is 7.07, while that of Hong Kong is 9.42, suggesting a medium difference, about 2.35, in product diversification between the two regions. The less diversified production in Hong Kong is due to its small area and scarce natural resources. Therefore, the difference between degrees of product diversification does not strongly support the hypothesis of adopting a common currency in Mainland China and Hong Kong.

Table 1: Degree of Product Diversification (1996-2003)

\begin{tabular}{|l|c|c|c|c|c|c|c|c|}
\hline & $\mathbf{1 9 9 6}$ & $\mathbf{1 9 9 7}$ & $\mathbf{1 9 9 8}$ & $\mathbf{1 9 9 9}$ & $\mathbf{2 0 0 0}$ & $\mathbf{2 0 0 1}$ & $\mathbf{2 0 0 2}$ & $\mathbf{2 0 0 3}$ \\
\hline Mainland,China & 7.17 & 7 & 8.78 & 6.91 & 6.85 & 6.60 & 6.48 & 6.79 \\
\hline Hong Kong & 10.14 & 9.78 & 9.91 & 9.15 & 9.05 & 8.95 & 9.33 & 9.04 \\
\hline
\end{tabular}




\section{Degrees of Openness}

Two measures are calculated to evaluate the degree of openness, which are the share of intra-regional trade in each of the regions' GDP and the share of total trade in GDP. These measures are shown in table 2 and table 3 respectively using data from International Financial Statistics by International Monetary Fund (IMF) and the International Trade Statistics Yearbook by UNIDO between 1999 and 2003. In addition, table 4 shows top three export and import partners of Hong Kong using data from the International Yearbook of Industrial Statistics by UNIDO from 1999 to 2003.

Table 2: Intra-regional Trade as a Share of GDP (\%) (1999-2003)

\begin{tabular}{|c|c|c|c|c|c|c|c|c|c|c|c|}
\hline Mainland China & 1999 & 2000 & 2001 & 2002 & 2003 & Hong Kong & 1999 & 2000 & 2001 & 2002 & 2003 \\
\hline Export to Hong Kong & 0.051 & 0.040 & 0.048 & 0.036 & 0.037 & $\begin{array}{l}\text { Export to Mainland } \\
\text { China }\end{array}$ & 0.416 & 0.402 & 0.384 & 0.366 & 0.366 \\
\hline Import from Hong Kong & 0.012 & 0.010 & 0.008 & 0.007 & 0.007 & $\begin{array}{l}\text { Import from Mainland } \\
\text { China }\end{array}$ & 0.501 & 0.479 & 0.460 & 0.458 & 0.494 \\
\hline Total Trade with Hong Kong & 0.063 & 0.050 & 0.056 & 0.043 & 0.044 & $\begin{array}{l}\text { Total Trade with } \\
\text { Mainland China }\end{array}$ & 0.917 & 0.881 & 0.844 & 0.824 & 0.860 \\
\hline
\end{tabular}

Table 3: Trade as a Share of GDP (\%)

\begin{tabular}{|l|c|c|c|c|c|l|c|c|c|c|c|}
\hline Mainland China & $\mathbf{1 9 9 9}$ & $\mathbf{2 0 0 0}$ & $\mathbf{2 0 0 1}$ & $\mathbf{2 0 0 2}$ & $\mathbf{2 0 0 3}$ & Hong Kong & $\mathbf{1 9 9 9}$ & $\mathbf{2 0 0 0}$ & $\mathbf{2 0 0 1}$ & $\mathbf{2 0 0 2}$ & $\mathbf{2 0 0 3}$ \\
\hline Exports/GDP & 0.212 & 0.183 & 0.202 & 0.191 & 0.197 & Exports/GDP & 1.248 & 1.174 & 1.101 & 1.069 & 1.100 \\
\hline Imports/GDP & 0.188 & 0.169 & 0.157 & 0.145 & 0.167 & Imports/GDP & 1.408 & 1.306 & 1.248 & 1.142 & 1.140 \\
\hline Total Trade/GDP & 0.400 & 0.352 & 0.359 & 0.336 & 0.364 & Total Trade/GDP & 2.656 & 2.480 & 2.349 & 2.211 & 2.240 \\
\hline
\end{tabular}

Table 4: Largest Trade Partner of Hong Kong

\begin{tabular}{|l|c|c|c|c|c|l|c|c|c|c|c|}
\hline \multicolumn{1}{|c|}{ Export } & $\mathbf{1 9 9 9}$ & $\mathbf{2 0 0 0}$ & $\mathbf{2 0 0 1}$ & $\mathbf{2 0 0 2}$ & $\mathbf{2 0 0 3}$ & \multicolumn{1}{|c|}{ Import } & $\mathbf{1 9 9 9}$ & $\mathbf{2 0 0 0}$ & $\mathbf{2 0 0 1}$ & $\mathbf{2 0 0 2}$ & $\mathbf{2 0 0 3}$ \\
\hline China & 0.333 & 0.343 & 0.349 & 0.342 & 0.333 & China & 0.356 & 0.367 & 0.369 & 0.401 & 0.439 \\
\hline United States & 0.218 & 0.212 & 0.218 & 0.237 & 0.238 & Japan & 0.147 & 0.134 & 0.135 & 0.125 & 0.116 \\
\hline & & & & & & $\begin{array}{l}\text { Other Asian } \\
\text { countries }\end{array}$ & 0.085 & 0.079 & 0.075 & 0.072 & 0.072 \\
\hline
\end{tabular}

Table 2 indicates large difference in the extent of intra-regional trade as the share of GDP between Mainland China and Hong Kong. For Mainland China, the trade with Hong Kong only takes up 5.12 percent of total GDP on average in the period 1999-2003. However, for Hong Kong, the trade with Mainland China accounts for 86.5 percent of total GDP on average for the same period. Table 3 suggests that Hong Kong is a highly open economy due to the fact that total trade of Hong Kong weighs averagely 238.72 percent of its total GDP. While Mainland China is less open than Hong Kong, as the total trade is 35.39 percent of its GDP on average. For the highly open economies, it is better to choose the fixed exchange rate system since the nominal exchange rate is not effective for adjustment as a policy instrument. Furthermore, table 4 shows that Mainland China is the largest trade partner of Hong Kong, accounting for 34 percent of export to and 38.6 percent of import from Hong Kong on average over the years of 1999-2003. However, for Mainland China, Hong Kong is the fifth largest export region and the largest import region. Consequently, considering the openness and the size of the economy, it is favorable for Hong Kong to adopt Yen and form a monetary union with Mainland China.

\section{Cyclical Co-variation in Economic Activities}

Four macroeconomic variables are examined to investigate whether the economic activities in the two regions move together. The four variables are real output growth, money growth, nominal interest rate, and real interest rate using data from International Financial Statistics by IMF between 1990 to 2004. Table 5 presents the regional correlations, means and standard deviations of these variables. Even though the data show that Mainland China and Hong Kong are positively correlated on the four variables, the correlations are weak, which make it 
difficult to judge whether the two regions are suitable to form a currency union.

Table 5: Correlation Matrix

\begin{tabular}{|c|c|c|c|c|c|c|c|c|c|}
\hline \multicolumn{5}{|c|}{ Output Growth 1990-2004 } & \multicolumn{5}{|c|}{ Money Growth 1991-2003 } \\
\hline & Mainland China & Hong Kong & Mean & Standard Deviation & & $\begin{array}{c}\text { Mainland } \\
\text { China }\end{array}$ & \begin{tabular}{|l|} 
Hong \\
Kong
\end{tabular} & Mean & $\begin{array}{l}\text { Standard } \\
\text { Deviation }\end{array}$ \\
\hline Mainland China & 1 & 0.383 & 0.090 & 0.027 & $\begin{array}{l}\text { Mainland } \\
\text { China }\end{array}$ & 1 & 0.250 & 0.212 & 0.069 \\
\hline Hong Kong & 0.383 & 1 & 0.038 & 0.034 & Hong Kong & 0.250 & 1 & 0.110 & 0.126 \\
\hline \multicolumn{5}{|c|}{ Nominal Interest Rate 1991-2003 } & \multicolumn{5}{|c|}{\begin{tabular}{|l|} 
Real Interest Rate 1990-2003 \\
\end{tabular}} \\
\hline & Mainland China & Hong Kong & Mean & Standard Deviation & & $\begin{array}{c}\text { Mainland } \\
\text { China }\end{array}$ & \begin{tabular}{|l|} 
Hong \\
Kong \\
\end{tabular} & Mean & $\begin{array}{l}\text { Standard } \\
\text { Deviation }\end{array}$ \\
\hline Mainland China & 1 & 0.365 & 0.064 & 0.030 & $\begin{array}{l}\text { Mainland } \\
\text { China }\end{array}$ & 1 & 0.434 & 0.008 & 0.0559 \\
\hline Hong Kong & 0.365 & 1 & 0.048 & 0.027 & Hong Kong & 0.434 & 1 & 0.007 & 0.054 \\
\hline
\end{tabular}

\section{Similarity of the Industry Structure}

I use the percentage contribution of industrial value added to analyze the extent of similarities in the industry structures. Table 6 presents the percentage contributions of various industrial sectors to value added in Mainland China and Hong Kong in 2003 using data from the International Yearbook of Industrial Statistics 2003, UNIDO. The results suggest little similarity in the industry structures of the two regions. The industrial products in Mainland China are more diversified than that in Hong Kong. In Mainland China, the leading sectors in value added are electrical machinery and industrial chemical, amounting to one-fourth of value added in total. They are followed by non-electrical machinery, transport equipment and textiles sectors. The rest of the industrial sectors contribute comparatively evenly to industrial value added. However, in Hong Kong, printing and publishing, electrical machinery, textile and non-electrical machinery dominate industrial value added. The contribution of the four sectors to value added is more than 50 percent. The difference in the industry structures implies that the two regions would be affected in the different ways by price shocks in the world market. Hence, Mainland China and Hong Kong may not be suitable for a monetary union.

Table 6: Percentage Contribution of Industrial Sectors to Value Added

\begin{tabular}{|c|c|c|c|c|c|}
\hline & $\begin{array}{c}\text { Mainland } \\
\text { China }\end{array}$ & Hong Kong & & $\begin{array}{l}\text { Mainland } \\
\text { China }\end{array}$ & Hong Kong \\
\hline Food products & 6.669 & 7.107 & $\begin{array}{l}\text { Misc. petroleum and coal } \\
\text { products }\end{array}$ & 1.346 & 0 \\
\hline Beverage & 3.606 & 2.407 & Rubber products & 2.347 & 0.147 \\
\hline Tobacco & 5.874 & 1.879 & Plastic products & 0.842 & 2.411 \\
\hline Textiles & 6.742 & 12.298 & Pottery, china, earthenware & 0.689 & 0 \\
\hline wearing apparel, except footwear & 3.195 & 9.102 & Glass and products & 0 & 0.247 \\
\hline Leather and fur products & 1.810 & 0.121 & $\begin{array}{l}\text { Other non-metallic mineral } \\
\text { products }\end{array}$ & 4.495 & 3.836 \\
\hline Footwear, except robber or plastic & 0 & 0 & Iron and steel & 6.517 & 0.385 \\
\hline Wood products, except furniture & 0.749 & 0.203 & Non-ferrous metals & 2.201 & 0.501 \\
\hline Furniture and fixtures, excl, metal & 0.510 & 0.144 & Fabricated metal products & 3.341 & 0 \\
\hline Paper and products & 2.055 & 1.323 & Non-electrical machinery & 7.836 & 10.851 \\
\hline Printing and publishing & 1.213 & 16.196 & Electrical machinery & 13.266 & 12.963 \\
\hline Industrial chemicals & 11.409 & 3.468 & Transport equipment & 7.160 & 0 \\
\hline Other chemicals & 0 & 0 & $\begin{array}{l}\text { Professional and scientific } \\
\text { equipment }\end{array}$ & 1.114 & 2.949 \\
\hline \multirow[t]{2}{*}{ Petroleum refineries } & 3.507 & 0 & Other manufacturing industries & 1.439 & 4.236 \\
\hline & & & Total & 100 & 100 \\
\hline
\end{tabular}




\section{Similarity of Inflation Rates}

Table 7: Average Percentage of Inflation Rates

\begin{tabular}{|l|c|c|c|c|c|c|}
\hline \multicolumn{1}{|c|}{ Regions } & \multicolumn{2}{c|}{$\mathbf{1 9 9 0 - 2 0 0 3}$} & \multicolumn{2}{c|}{$\mathbf{1 9 9 0 - 1 9 9 7}$} & \multicolumn{2}{c|}{ 1998-2003 } \\
\hline & Mean & Standard Deviation & Mean & Standard Deviation & Mean & Standard Deviation \\
\hline Mainland China & 5.350 & 7.791 & 9.988 & 7.839 & -0.183 & 0.930 \\
\hline Hong Kong & 3.730 & 5.888 & 8.725 & 1.848 & -2.000 & 2.546 \\
\hline
\end{tabular}

Table 7 summarizes the means and standard deviations of inflation rates in Mainland China and Hong Kong over the period of 1990-2003 using data from International Financial Statistics, IMF. The statistics shows that the level and volatility of inflation rates are different in the two regions over the period of 1990-2003. Furthermore, the inflation rates were higher and more volatile in Mainland China before 1997 than in Hong Kong. However, between 1997 and 2003, both Mainland China and Hong Kong experienced the deflation due to Asia financial crisis in 1997 and economic recession in the U.S. in 2001. In this period, Mainland China exhibited lower deflation rate and smaller volatility in inflation rates than Hong Kong. Therefore, the difference in the means and variations of inflation rates between Mainland China and Hong Kong does not support the hypothesis of a currency union.

\section{CONCLUSION}

This paper examines five economic indicators to assess the possibility of forming a currency union between Mainland China and Hong Kong and find mixed results. The higher product diversification in Mainland China, low correlations in real output growth, money growth, nominal interest rate and real interest rate, and dissimilarity of industry structures and inflation rates do not support the formation of a currency union between the two regions. However, the analysis of degrees of openness is in favor of a monetary union between Mainland China and Hong Kong. Nevertheless, migration between Mainland China and Hong Kong was very small before July1, 1997. Even after that, migration is still small since Hong Kong only introduces highly skilled labor. Culturally, English was the official language before July 1, 1997 and Cantonese is widely used in Hong Kong, resulting in difficult communication between Hong Kong and Mainland China, where Mandarin is the official language. Therefore, it is not favorable to constitute a currency union between Mainland China and Hong Kong at the present time.

\section{AUTHOR INFORMATION}

Hong Zhuang is an assistant professor of economics at Indiana University South Bend. Dr. Zhuang receives her $\mathrm{PhD}$ from University of Oregon, Eugene, Oregon, U.S.A. Her specialized field is international economics and economic growth.

\section{REFERENCES}

1. Bayoumi, T., \& Ostry, J. D. (1997). Macroeconomic Shocks and Trade Flows within Sub-Saharan Africa: Implications for Optimum Currency Arrangements. Journal of African Economies, 6(3), 412-444.

2. Dellas, H., \& Tavlas, G. S. (2001). Lessons of the Euro for Dollarization - Analytic and Political Economy Perspectives. Journal of Policy Modeling, 23(3), 333-345.

3. Dupasquier, C., \& Jacob, J. (1997). European Economic and Monetary Union: Background and Implications. Bank of Canada Review, 1997 (Autumn), 3-28.

4. Frankel, J. A., \& Rose, A. K. (1996). Economic Structure and the Decision to Adopt a Common Currency. Seminar Papers, No. 611, Stockholm University, Institute for International Economic Studies.

5. Frankel, J. A., \& Rose, A. K. (2000). Estimating of the Effect of Currency Unions on Trade and Output. NBER Working Papers, No. 7857.

6. Garganas, N., \& Tavlas, G. S. (2001). Monetary Regimes and Inflation Performance: The Case of Greece. In R. Bryant, N. Garganas \& G. S. Tavlas (Eds.), Greece's Economic Performance and Prospects. Athens: Bank of Greece and The Brookings Institution. 
7. Grauwe, P. d. (1997). The Economics of Monetary Integration. Oxford; New York: Oxford University Press.

8. Jonung, L., \& Sjoholm, F. (1998). Should Finland and Sweden Form a Monetary Union? Working Papers Series in Economics and Finance, No. 224, Stockholm School of Economics.

9. Kenen, P. (1969). The Theory of Optimum Currency Areas: An Eclectic View. In R. Mundell \& A. Swoboda (Eds.), Monetary Problems of the International Economy (pp. 41-60). Chicago: The University of Chicago Press.

10. Mckinnon, R. I. (1963). Optimum Currency Areas. American Economic Review, 53, 717-724.

11. Mkenda, B. K. (2001). Is East Africa an Optimum Currency Area? Working Papers in Economics, No. 41, Goteborg University.

12. Rose, A. K. (2000). One Money, One Market: Estimating the Effect of Common Currencies on Trade. Economic Policy, 15(30), 7-45.

13. Rose, A. K. (2001). Common Currency Areas in Practice: Bank of Canada.

14. Rose, A. K., \& Engel, C. (2002). Currency Union and International Integration. Journal of Money, Credit and Banking, 34(3), 804-826.

15. Tavlas, G. (1993). The 'New' Theory of Optimal Currency Areas. The World Economy, 16(6), 663-685. 
NOTES 